\title{
The plurality of values in sustainable agriculture models: diverse lock-in and coevolution patterns
}

\author{
Gael Plumecocq $^{1,2}$, Thomas Debril $^{1}, \underline{\text { Michel Duru }}^{1}, \underline{\text { Marie-Benoit Magrini }}^{1,2}, \underline{\text { Jean Pierre Sarthou }}^{1}$ and $^{\text {Olivier Therond }}{ }^{3}$
}

\begin{abstract}
In Western economies, several agriculture models coexist. For instance, intensive agriculture organization, which has increased yields while causing major pollution and resource depletion, competes with alternative models, which tackle these sustainability issues and lead to lower yields. An agronomical typology of current agriculture models in Western societies is proposed that describes multiple sustainability issues through an agroecological perspective. However, in order to choose between these agroecological pathways, we must understand their social structure and the principles underlying them. Thus, our purpose is to characterize the institutional aspects of the alternative models using socioeconomic convention theory. We conducted a series of workshops with specialists in the natural sciences (agronomy, landscape ecology, and entomology) and social sciences (economics and sociology) to describe sustainable agriculture models. This characterization revealed the values underlying six different sustainable agriculture models, their forms of organization, and the institutions governing them. We discuss the implications of the coexistence of these six models in light of sustainable transition issues. From this coexistence perspective, transition (i) refers to an intertwined process of legitimation and disqualification, and (ii) means seeing pathways as the multiplicity and degree of interconnection between models. Therefore, we (i) identified the elements in each model that legitimize its mode of organization, and (ii) disqualified the elements that are incompatible with the principles underlying the model's practices. Moreover, we emphasize that multiple transition pathways are possible based on complex, complementary combinations of different models. This revealed the intricate processes of competition and complementarity involving these models. Finally, our study on the coexistence, interdependence, and coevolution of multiple agriculture models led us to advocate a precautionary principle so that marginal innovative models are not prevented from emerging.
\end{abstract}

Key Words: agroecology; convention theory; ecosystem service; farming system; food system; sustainable agriculture; transition

\section{INTRODUCTION}

The high-yield, conventional agriculture model based on the use of synthetic inputs (such as pesticides, nitrogen fertilizers, and antibiotics), minerals (potash and phosphates), and water has negative impacts on the natural environment that are well-known today (Rockström et al. 2009, German et al. 2016). Awareness of these impacts and the ensuing environmental regulations have pushed farmers to change their relationship to nature (Horlings and Marsden 2011, Duru et al. 2015a, b). Many authors have identified distinct pathways that agriculture can take to improve sustainability. In the late 1990s, Hill (1998) contrasted "shallow" with "deep" sustainability. More recently, Wilson (2008) spoke of "weak versus strong multifunctionality," Horlings and Marsden (2011) of "weak versus strong ecological modernization of agriculture," and Levidow et al. (2013) of "life sciences versus an agroecology vision." These conceptual dichotomies oppose two kinds of agroecological practices (i.e., two kinds of relationships to nature): one that considers technological progress as the way to address environmental issues, and another that targets better protection or restoration of natural capital to increase ecosystem services. Most of the authors of these dichotomies acknowledge that there is some middle ground. Other authors have attempted to identify provisional models. However, the rare typologies that identify more than two models of agriculture tend to either overlook their moral foundations (Therond et al. 2017) or grant moral status only to the "strongest" or "deepest" agroecological models (Gliessman 2007).

Thus, while all these studies agree on certain characteristics of agriculture models, they do not question the moral justifications used to legitimize choices, nor do they question the social aspects of individual strategies and practices. Although these sustainable agriculture models are based on different systems of social values, they currently coexist. Multiple sustainability transitions of agriculture are then possible, depending on how the values legitimizing these models coevolve. Therefore, we need to understand in greater depth the variety of farmers' motivations for choosing a particular pathway. However, choosing one model may lead to the lock-in of the others. Thus, to best adapt public policies for transforming agriculture, we need to examine the underlying principles of these multiple models and their interdependencies. To do so, we build on a fine-grained agronomic typology of Western sustainable agriculture models that was recently developed by some authors of this paper (Therond et al. 2017). This typology identifies coherent sets of agricultural practices and technologies that deal with sustainability issues. We link these practices together with the moral values that legitimize them through an institutional characterization of each model based on "convention theory" (see Ponte 2016 for a review of the use of the convention theory in English agro-food literature). We draw on Boltanski and Thévenot (2006), who provide a framework - the "economies of worth" model — for qualifying the organizing principles and social values that underlie the institutional features of various legitimate social systems. We explicate how practices are embedded into institutional contexts and refer to greater common good (e.g., the use of petrochemicals in conventional farming practices is justified by the "feeding the world" argument). When practices are collectively judged as admissible (i.e., when justifications are collectively accepted and draw on conventionally accepted social values), they provide the basis for collective actions and possibly social systems. Boltanski

${ }^{1}$ INRA, AGIR, Université de Toulouse, INRA, INPT, INP-EI PURPAN, Castanet-Tolosan, France, ${ }^{2}$ LEREPS, Université de Toulouse, France, ${ }^{3}$ INRA, LAE, Université de Lorraine, Colmar, France 
and Thévenot (2006) identified six types of common good in political philosophy in relation to six forms of social organization (i.e., "polities"):

- equity as the basis of civic forms of organization in the work of Rousseau

- honesty as the basis of domestic forms of organization in the work of Bossuet

- grace as the basis of inspired forms of organization in the work of Augustine

- efficiency as the basis of industrial forms of organization in the work of Saint-Simon

- richness as the basis of market forms of organization in the work of Adam Smith

- fame as the basis of organizations whose form is based on opinion in the work of Hobbes

Traces of these political philosophies can be found in the social world (understood as an internally consistent arrangement of objects and persons). Particular material arrangements such as technology, or certain institutional ones such as product quality or rules of organization, then inscribe objects in one of these polities or qualify social functions in regard to one of these common goods. Thévenot (1984) terms these "investments in form" to designate the various instruments listed in a given world (e.g., tools, habits, rules, or diverse material sets of arrangements). These investments in form then frame practices and collective actions. For instance, standards or labels may determine the form of production processes that are organized according to principles of equity or efficiency (Ponte 2016). Yet the complexity of social worlds results from the fact that, very often, forms of organization are established as a compromise between several "pure" polities. The "investments" made to put practices in a particular form then borrow elements from various polities (see the text box for a list of selected elements that constitute a polity).

This article is organized as follows. In Section 2, we present the methodology and data. We explain the interdisciplinary method used for the institutional characterization of these models, which we built on a typology of sustainable agriculture models. This typology was established on farming systems depending on whether they are based on exogenous input or ecosystem services, and high or low "territorial embeddedness." In Section 3, we analyze this sustainable agriculture model typology using the economies of worth model and emphasize their institutional features (e.g., rules of functioning, forms of organization, principles for justifying prevailing practices). This institutional characterization of sustainable agriculture models provides categories for conceptualizing the influence of human-naturetechnology relationships on modes of social organization, agricultural practices, and uses of nature, and the institutional and political forms that regulate those practices and uses. Section 4 presents a discussion on the coexistence and coevolution of these models, as well as on how to support agriculture as it changes to meet the challenges of agroecology. Transition, from a coexistence perspective, then (i) refers to an intertwined process of legitimation and disqualification, and (ii) leads to understanding pathways through the multiplicity and degree of interconnection between models.
Box 1:

The economies of worth grammar from Boltanski and Thévenot (2006)

Higher common principle: "principle of coordination that ... is a convention for establishing equivalence among beings."

State of worthiness: "Worth beings are guarantors of the higher common principle."

List of subjects: type of people "most often qualified by their state of worth (unworthy beings or worthy beings)."

List of objects and arrangements: "when objects, or their combination in more complicated arrangements, are arrayed with subjects, in situations that hold together, they may be said to help objectify the worth of the person involved."

Investment formula: "worth also presupposes the sacrifice of the private pleasures associated with a state of lesser worthiness."

Natural relations among beings: "these relations ... must be in harmony with the worths of the subjects and objects that they unite according to relations of equivalence and order established by the polity."

Harmonious figure of the natural order: "the relation of equivalence can be known only to the extent that it is revealed by a harmonious distribution of state of worth ... in conformity with the investment formula."

Model test: "a situation that holds together ... is prepared for a test ... that entails a pure and particularly consistent arrangement of beings from a single world."

Mode of expression of judgment: "characterizes the form in which the higher common principle is manifested."

Form of evidence: "modality of knowledge appropriate to the world under consideration."

\section{METHOD AND (TYPOLOGY) DATA}

\section{Method: an interdisciplinary and feedback study}

This study expanded on a preliminary version of an agronomical typology of farming systems that addressed sustainability issues (Duru et al. 2016). At the same time, a socioeconomic characterization of that agronomic typology was also developed. This work resulted in a fine-grained typology of six sets of agroecological farming practices embedded in different food systems, which we briefly present in the next subsection (Therond et al. 2017). We then conducted a series of workshops involving the two authors of the typology (one working in agronomy, the other in landscape ecology), an entomologist, a sociologist, an economist, and a socioeconomist.

During these workshops, natural scientists extensively presented how they conceived of each of the sustainable agriculture models in the agronomical typology. After each model was presented, social scientists evaluated the extent to which each model could be described in terms of the economies of worth grammar; e.g., 
by asking "who is recognized as dominant in this model?" (i.e., what is the "state of worthiness" in the economies of worth grammar), or "how can we know that a figure in this model is dominant?" (i.e., what is the "model test" prevailing in this sustainable agriculture model?).

Discussions between natural and social scientists resulted in three outcomes. First, the agronomical construction of the models was refined (the socioeconomic descriptions given called for further agronomical specifications). Interdisciplinary work then helped the participants reformulate disciplinary questions or issues. Second, discussions led natural scientists to refine the way they described these models to the social scientists (the socioeconomic descriptions dissipated misunderstandings in the descriptions). Third, these exchanges enabled the researchers to settle on the formal descriptions of the agronomic models in socioeconomic terms. The method process is described in Fig. 1.

Fig. 1. Interdisciplinary feedback process.

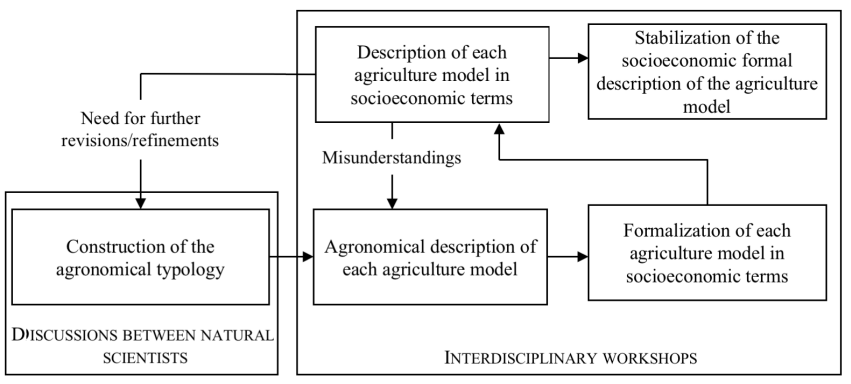

This study is interdisciplinary in nature, meaning that knowledge exchange occurred among researchers from different disciplines. First, social scientists (economics and sociology) acquired a background in natural science that helped them grasp the consistency of the sustainable agriculture models described in agroecological terms, which they needed in order to understand them as social systems. Second, the way in which natural scientists (an agronomist, landscape ecologist, and entomologist) described the agricultural models was challenged by the socioeconomic views.

\section{The typology of farming systems and agriculture models}

In the typology by Therond et al. (2017), two ways of characterization were used to define six alternative sustainable agriculture models (Fig. 2).

Iconic examples are presented in grey. The number 1 is for conventional farming systems outside less-favored areas ( 1 being the current, conventional agriculture model). The main alternative agriculture models were grouped into two types of alternatives to reflect the paradigm shift between input-based (type-2) versus biodiversity-based farming systems (type-3). Submodels labeled a, b, and c mainly reflect the relationships between farming systems, globalized food systems, and local dynamics.

Exogenous inputs versus ecosystem services

The first criterion used to classify sustainable agriculture models is the input used in farming systems. This dimension concerns the ways in which farmers adapt internal characteristics of their farming system to account for societal demands for natural resource preservation. This criterion reflects a wide range of farming system strategies using combinations of inputs that are different in nature (exogenous versus endogenous):

- Some farmers try to deal with environmental issues by using technologies to increase input use efficiency and limit pollution. One strategy uses agriculture precision technologies to apply the right product, at the right rate, at the right time and right place (Spiertz 2012). A second practice replaces chemical inputs with more "environmentally friendly" ones, such as organic fertilizers and exogenous biocontrol technologies (biopesticides, soil and plant health stimulators, industrially developed organisms involved in soil nutrients, and biological regulation). These two strategies are dominant in farming systems $2 \mathrm{a}$ and $2 \mathrm{~b}$, respectively (Fig. 2).

- On the other end of the spectrum, farmers develop and manage biodiversity to increase ecosystem services to agriculture or "input services" (Zhang et al. 2007, Duru et al. 2015a). This practice seeks to replace a large part of synthetic or biological inputs with natural biological regulators in order to enhance soil fertility (soil structure and nutrient cycling), water storage, pollination, and pest regulation. These strategies are dominant in farming systems $3 \mathrm{~b}$ and $3 \mathrm{c}$ (Fig. 2).

These farming system strategies are not mutually exclusive. Farming systems that combine endogenous and exogenous inputs must then accurately assess the level of ecosystem services in time and space (e.g., nitrogen and water provisioning) in order to optimize the necessary level of additional anthropogenic inputs required to reach the target production level.

\section{Low versus high territorial embeddedness}

Farming systems are linked to food systems, which have diverse sets of institutions, technologies, and practices for producing, processing, packaging, distributing, retailing, and consuming food. They are also involved in other territorial dynamics that determine agricultural practices (nature of inputs and outputs, technology used) depending on their level of "territorial embeddedness" (Sonnino and Marsden 2006). Therond et al. (2017) used the level of farming systems' territorial embeddedness as the second criterion for their typology.

First, farming systems may be embedded in industrial, globalized, commodity-based food systems that process inputs (e.g., fertilizers, pesticides), animal feed (e.g., soy bean meal), raw/bulk agricultural commodities (e.g., wheat), minimally processed foods (e.g., durum wheat semolina), and, increasingly, fractionated raw products in standardized and often interchangeable components (e.g., sugars, oils) and ultraprocessed foods based on these components (Marsden 2012, Monteiro et al. 2013, Khoury et al. 2014). In these food systems, social relationships are driven mainly by globalized market prices, and territorial embeddedness of farming systems is low. Farming systems $2 \mathrm{a}, 2 \mathrm{~b}$, and $3 \mathrm{a}$ are quite embedded in these globalized food systems.

Second, some farming systems are involved in place-specific approaches (or initiatives), like circular economies (such as in model 3a, Fig. 2), alternative food systems (such as in model 3b, 
Fig. 2. Main models of agriculture (from 1 to $3 b$ in blue) with farming systems identified based on their varying degrees of use of ecosystem services versus anthropogenic exogenous inputs (Y-axis) and connected to globalized food systems or local dynamics (Xaxis). Iconic examples are presented in grey. The number 1 is for conventional farming systems outside less-favored areas (1 being the current, conventional agriculture model). The main alternative agriculture models were grouped into two types of alternatives to reflect the paradigm shift between input-based (type-2) versus biodiversity-based farming systems (type-3). Submodels labeled a, b, and c mainly reflect the relationships between farming systems, globalized food systems, and local dynamics. (CA:conservation agriculture; FS:farming system; ICLS:integrated crop livestock systems).

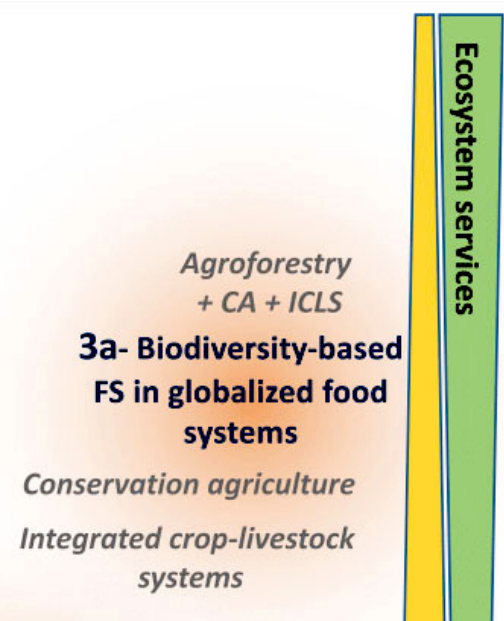

\section{Integrated \\ landscape project}

3C- Biodiversity-based FS

in alternative food systems and circular economy and collectively managed multiservice landscape 3b- Biodiversity-based FS

in alternative food systems and circular economy

Territorial embeddedness

Globalized commodity-based food systems

\section{2b- Biological input- based FS in globalized commodity-based food systems}

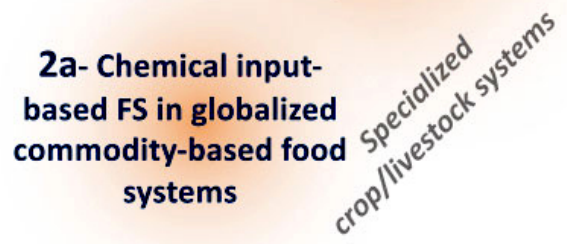

1- Conventional FS

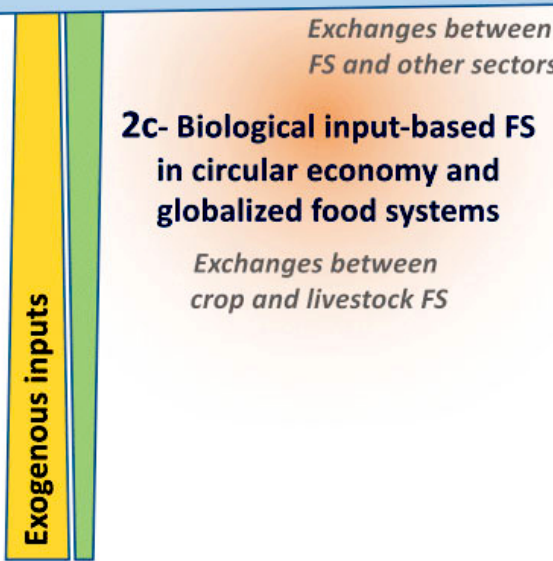

and possibly 2b, Fig. 2), and integrated landscape approaches (such as in model 3c, Fig. 2). As such, they increasingly meet multiple socioeconomic and environmental objectives at the local or regional level. These forms of farming systems' territorial embeddedness can relate either to upstream or downstream activities of agro-food chains: a given farming system can be linked to a globalized food system for its supply (e.g., industrial inputs or seeds) but linked to local markets for the distribution of end products. On the contrary, farming systems can also be part of a local production sector, as with the circular economy, but retail their end products on global markets.

\section{INSTITUTIONAL CHARACTERIZATION OF AGRICULTURE MODELS}

In this section, we analyze the institutional characteristics of the sustainable agriculture models in the typology using the economies of worth grammar (Boltanski and Thévenot 2006). We begin by presenting each model, detailing its agronomical and institutional features, and then qualify it according to its underlying compromises. The main elements are summarized in Table 1. We then examine the ways in which some models follow the historical-conventional model fairly closely and merely make adjustments to it, while others were created in opposition to that model as a radical break from it.

The historical-conventional model based on an industrial/market compromise

The historical model of agriculture in Western economies is strongly based on technological innovations (e.g., chemical synthesis of soil nutrients, genomic and genetic modification of seeds and livestock) that increased agricultural production. This type of farming system is traditionally and hereafter called "conventional" (1 in Fig. 2). It refers to a system of practices 
Table 1. Institutional characterization of current Western sustainable agriculture models.

\begin{tabular}{|c|c|c|c|c|c|c|}
\hline $\begin{array}{l}\text { Agriculture models } \\
\text { Historical- } \\
\text { conventional model } \\
\text { (1) } \\
\end{array}$ & $\begin{array}{l}\text { Technology- } \\
\text { intensive model (2a) }\end{array}$ & Biotech model (2b) & Circular model (2c) & $\begin{array}{l}\text { Diversified- } \\
\text { globalized model } \\
\text { (3a) }\end{array}$ & $\begin{array}{l}\text { Relocalized model } \\
\text { (3b) }\end{array}$ & $\begin{array}{l}\text { Integrated-landscape } \\
\text { model (3c) }\end{array}$ \\
\hline \multicolumn{7}{|l|}{ Common worlds involved } \\
\hline $\begin{array}{l}\text { Industrial/ } \\
\text { market }\end{array}$ & $\begin{array}{l}\text { Industrial/ } \\
\text { market }\end{array}$ & $\begin{array}{l}\text { Domestic/ } \\
\text { industrial/ }\end{array}$ & $\begin{array}{l}\text { Industrial/ } \\
\text { green }\end{array}$ & $\begin{array}{l}\text { Opinion/ } \\
\text { industrial... }\end{array}$ & $\begin{array}{l}\text { Opinion/domestic/ } \\
\text { market... }\end{array}$ & $\begin{array}{l}\text { Green/ } \\
\text { domestic/civic... }\end{array}$ \\
\hline \multicolumn{7}{|c|}{ Higher common principle } \\
\hline $\begin{array}{l}\text { Independence, food } \\
\text { security, product } \\
\text { diversity }\end{array}$ & $\begin{array}{l}\text { Same as in } 1 \\
\text { Efficiency and well- } \\
\text { being at work }\end{array}$ & $\begin{array}{l}\text { Ethic of nature and } \\
\text { human heath }\end{array}$ & $\begin{array}{l}\text { Overall efficiency at } \\
\text { the cluster scale }\end{array}$ & $\begin{array}{l}\text { Ability to put } \\
\text { nature to work and } \\
\text { "one health" (farm } \\
\text { level) }\end{array}$ & $\begin{array}{l}\text { Same as in } 3 \mathrm{a} \\
\text { Ability to create } \\
\text { value for farmers } \\
\text { and for the region }\end{array}$ & $\begin{array}{l}\text { Systemic thought, } \\
\text { biodiversity principle, } \\
\text { "one health" } \\
\text { (ecosystem level) }\end{array}$ \\
\hline \multicolumn{7}{|c|}{ Form of relevant proof (worth) } \\
\hline $\begin{array}{l}\text { Labor productivity, } \\
\text { farm size, balance } \\
\text { sheet, production } \\
\text { level, agricultural } \\
\text { exports }\end{array}$ & $\begin{array}{l}\text { Production costs, } \\
\text { structure of } \\
\text { investments, high- } \\
\text { tech devices }\end{array}$ & $\begin{array}{l}\text { Extended socio- } \\
\text { environmental costs, } \\
\text { good sanitary } \\
\text { conditions, } \\
\text { environmental } \\
\text { indicators }\end{array}$ & $\begin{array}{l}\text { Waste-production } \\
\text { balance at the } \\
\text { cluster level, } \\
\text { recycling rate }\end{array}$ & $\begin{array}{l}\text { Sustainable use of } \\
\text { nature, opinion of } \\
\text { peers }\end{array}$ & $\begin{array}{l}\text { Same as in } 3 a \\
\text { Distance to local } \\
\text { food system, farmer } \\
\text { income, added value } \\
\text { for the region }\end{array}$ & $\begin{array}{l}\text { Systemic (multilevel, } \\
\text { multicriteria, multi- } \\
\text { actor) }\end{array}$ \\
\hline \multicolumn{7}{|l|}{ Qualified objects } \\
\hline $\begin{array}{l}\text { Petrochemical } \\
\text { inputs, mechanical } \\
\text { infrastructures, } \\
\text { production } \\
\text { standards }\end{array}$ & $\begin{array}{l}\text { Same as in } 1 \\
\text { Connected and } \\
\text { high-tech devices }\end{array}$ & $\begin{array}{l}\text { Same as in } 2 \mathrm{a} \\
\text { Biological inputs, } \\
\text { recycling farm } \\
\text { equipment }\end{array}$ & $\begin{array}{l}\text { Same as in } 2 \mathrm{~b} \\
\text { Biogas production, } \\
\text { waste recycling } \\
\text { equipment, } \\
\text { coproducts }\end{array}$ & $\begin{array}{l}\text { Natural capital and } \\
\text { ecosystem services, } \\
\text { petrochemical and } \\
\text { biological inputs }\end{array}$ & Same as in $3 a$ & $\begin{array}{l}\text { Same as in } 3 \mathrm{a} \\
\text { Landscape } \\
\text { heterogeneity }\end{array}$ \\
\hline \multicolumn{7}{|l|}{ Qualified human beings } \\
\hline $\begin{array}{l}\text { Productive farmer, } \\
\text { mass consumer }\end{array}$ & $\begin{array}{l}\text { High-tech farmer/ } \\
\text { entrepreneur, mass } \\
\text { consumer }\end{array}$ & $\begin{array}{l}\text { Socially responsible } \\
\text { farmer, family, } \\
\text { neighborhood }\end{array}$ & $\begin{array}{l}\text { Same as in } 2 b \\
\text { Cluster member }\end{array}$ & $\begin{array}{l}\text { Agroecologist } \\
\text { farmer, agricultural } \\
\text { ecosystem }\end{array}$ & $\begin{array}{l}\text { Same as in } 3 \\
\text { Trader farmer, } \\
\text { consumer } \\
\text { committed to local }\end{array}$ & $\begin{array}{l}\text { Same as in } 3 \mathrm{~b} \text { Local } \\
\text { actors and } \\
\text { ecosystems, network } \\
\text { member }\end{array}$ \\
\hline \multicolumn{7}{|l|}{ Time of formation } \\
\hline $\begin{array}{l}\text { Short economic } \\
\text { term }\end{array}$ & Same as in 1 & $\begin{array}{l}\text { Short- to middle- } \\
\text { term biological } \\
\text { cycles }\end{array}$ & Same as in $2 b$ & $\begin{array}{l}\text { Short-, middle-, and } \\
\text { long-term } \\
\text { ecological cycles }\end{array}$ & Same as in $2 \mathrm{a}$ & $\begin{array}{l}\text { Short-, middle-, and } \\
\text { long-term ecological } \\
\text { and social cycles }\end{array}$ \\
\hline \multicolumn{7}{|c|}{ Space in which the model is formed } \\
\hline Globalization & $\begin{array}{l}\text { Same as in } 1 \\
\text { Infra-parcel }\end{array}$ & $\begin{array}{l}\text { Same as in } 1 \\
\text { Socio- } \\
\text { environmental } \\
\text { neighborhood }\end{array}$ & $\begin{array}{l}\text { Local industrial } \\
\text { clusters }\end{array}$ & $\begin{array}{l}\text { Peer communities, } \\
\text { ecological } \\
\text { environment of } \\
\text { farm }\end{array}$ & $\begin{array}{l}\text { Same as in 2a Local } \\
\text { markets }\end{array}$ & $\begin{array}{l}\text { Same as in } 2 \mathrm{~b} \text { Local } \\
\text { system, social } \\
\text { networks }\end{array}$ \\
\hline \multicolumn{7}{|l|}{ Mode of regulation } \\
\hline $\begin{array}{l}\text { Contracts, } \\
\text { intellectual property } \\
\text { rights, incentives } \\
\text { and financial } \\
\text { support, production } \\
\text { standards, } \\
\text { command and } \\
\text { control }\end{array}$ & Same as in 1 & Same as in 1 & $\begin{array}{l}\text { Same as in 1, Local } \\
\text { industrial } \\
\text { partnerships }\end{array}$ & $\begin{array}{l}\text { Peer associations, } \\
\text { labels, quality } \\
\text { certifications, } \\
\text { adaptive } \\
\text { management of } \\
\text { field }\end{array}$ & $\begin{array}{l}\text { Same as in } 2 \mathrm{a} \\
\text { Local markets }\end{array}$ & $\begin{array}{l}\text { Local system, } \\
\text { adaptive } \\
\text { management of } \\
\text { landscape }\end{array}$ \\
\hline \multicolumn{7}{|c|}{ Mode of organization/coordination } \\
\hline $\begin{array}{l}\text { Markets, global } \\
\text { food systems }\end{array}$ & $\begin{array}{l}\text { Same as in } 1 \\
\text { Technologies shape } \\
\text { relationship to } \\
\text { nature, new markets }\end{array}$ & Same as in $2 a$ & $\begin{array}{l}\text { Industrial ecology } \\
\text { organization, loop- } \\
\text { backed input- } \\
\text { output production }\end{array}$ & $\begin{array}{l}\text { Peer communities, } \\
\text { global food system }\end{array}$ & $\begin{array}{l}\text { Same as in } 2 \mathrm{a} \\
\text { Peer communities, } \\
\text { local markets }\end{array}$ & $\begin{array}{l}\text { Same as in } 2 b \\
\text { Polycentric } \\
\text { organization, } \\
\text { adaptive governance }\end{array}$ \\
\hline
\end{tabular}

oriented toward, organized around, and institutionalized through industrial productivity and market-based considerations. These industrial and market principles are based on standardizing infrastructure, production technology (machinery, petrochemical inputs), and end products that can be mass-produced and distributed. Striving for efficiency and profitability comes together in economies of scale and agglomeration, which concentrate production to reduce unit costs. Agricultural practices are oriented mainly toward reducing the unpredictable aspects of farming. In this sense, using more synthetic inputs than needed in a given year to limit risks (such as pests) and to promote plant growth, or antibiotics to ensure animal health, is traditionally done as an "insurance" practice. This system is widespread in areas without strong soil and climate limitations.

Production strategies are conceived in terms of relatively short time frames (short crop rotations). The global standardization of seeds, breeds, production technologies, and products means that the specificities of local ecosystems are not really taken into account. This system is based on an instrumental relationship with nature and the farming system being highly integrated into 
the socio-agrotechnical system. Consequently, this conventional system is fundamentally underpinned by the principle of productivity, which institutionalizes and legitimizes the industrial and market-based organization of this system. The common good served by this model is national and global food sovereignty; i.e., the idea that no one in the world should starve.

\section{The technology-intensive model based on an industrial efficiencyl market profitability compromise}

The first sustainable agriculture model (2a in Fig. 2) is a chemical input-based farming system (specialized cash crop and livestock farms) embedded in industrial, globalized food systems. To reach its (weak) sustainability objective, the focus is either on developing "smart" agricultural technologies (i.e., genetic engineering and precision farming) or knowledge about landscape features that minimize diffusion of pollutants in aquatic ecosystems (e.g., grassy and riparian buffer strips/zones). Accordingly, we have termed it the technology-intensive model.

In this technology-intensive model, changing farming practices is motivated by the idea that technological mastery can meet environmental requirements and reduce production costs and thus improve farmers' incomes. By integrating the latest scientific knowledge in decision support systems, this sustainable agriculture model indeed has the potential to improve agricultural as well as environmental performance of conventional farming systems (reducing pollution in the soil, in water resources, and in the atmosphere). Strong economic limitations of markets both upstream (increased cost of inputs) and downstream (market price variability) and environmental regulations also encourage farmers of the historical-conventional model to increasingly adopt the technology-intensive one.

The economic resilience of this synthetic-input-based farming system to price variability and biophysical risks can be supported, respectively, by contracts and insurance schemes, both provided by globalized food supply chain organizations. These protections may lead farmers to increase the share of riskier cash crops, thereby resulting in an increased share of monocultures (Müller and Kreuer 2016). Moreover, as farmers adopt these costly new technologies, they often increase their acreage to ensure scale economies. Accordingly, this kind of farming system is often poorly connected with local natural resource management issues and strategies, which can lead to conflicts about water shortages due to irrigation, water quality due to pollution, or erosion due to bare soils (O'Kane 2012).

The search for efficiency and profitability justifies using technology by making it part of a compromise between the industrial world and the market world. Thus, as in the conventional model, human-nature relationships are mediated by increasingly sophisticated digital technologies. The common good served by this model is still national and global food sovereignty, but it also involves a techno-optimistic conception of social progress, which can be viewed as an updating of the conventional model. Change with this type of farming system remains driven mainly by the dynamics of globalized food systems in which power is concentrated in large retailers (Marsden 2011). Changes in this model therefore generally require incremental adaptations of the conventional model (Park et al. 2012). As a result, this sustainable agriculture model is the dominant one in Western Europe (Müller and Kreuer 2016).

\section{The biotech model based on a domestic proximity/industrial} efficiency compromise

The second sustainable agriculture model (2b in Fig. 2) corresponds to a biological input-based farming system (which we have termed the biotech model). In this model, farming systems are connected to globalized food systems for purchasing biological inputs and selling raw products to the global composite and bioeconomy markets. Adopting these "new" biological technologies is motivated by an awareness of the local health (of neighbors and relatives) and environmental effects of conventional farming practices. Productive efficiency remains an important goal of these farming systems since they are embedded in globalized, commodity-based food systems. The common good served in this model is therefore in a state of tension between health care and environmental preservation at the local scale, which makes farmers receptive to environmental ethics, and the common good of food sovereignty and modernizing agriculture at the national or global scale.

This tension is a constituent characteristic of this model. Although the efficacy of technologies from the life sciences has been demonstrated for some uses of iconic living inputs, such as inoculating Rhizobia into legume cropping systems (Lemanceau et al. 2015), the actual effects at field level of many ecological inputs such as biostimulants have not been conclusively proven. Using these practices is then based on the belief (in the sense of lack of proof) that they can both improve the productive capacity of soils and plants (by stimulating soil activity and plant health) and limit the environmental and health impacts of agriculture (from the lower ecotoxicity of biological inputs). The health care/ environmental value system, therefore, overcomes the lack of proof to strengthen the idea that the farming practices prevailing in this model are good practices.

Yet these biological technologies (e.g., biocontrol) require greater consideration of the ecological timescale (for example, when introducing natural enemies). In this model, there are no overall changes to the production system or broader environmental concerns (e.g., landscape management). These practices, therefore, do not result in a strong noninstrumental relationship with nature. Organic farming, which has a very different set of practices and value systems (see Allaire and Bellon 2014), is compatible with this model since the synthetic inputs used in the historical-conventional model and the technology-intensive model are replaced by biological inputs. However, there is no fundamental change in the farming system (e.g., it still uses specialized crop cultures, intensive practices).

These first two models (technology-intensive and biotech) still follow the conventional model in that the farmers' primary concern is still to ensure the productive capacity of land and animals by technologically controlling the uncertainties of farming. Since the technology-intensive and biotech models do not challenge the governing values (Argyris and Schön 1996) that shape and give meaning to the historical-conventional model, they do not require (technological-intensive), or require only minimally (biotech), rethinking the organizational (market) and institutional forms (standardization) that they are based on. Instead, these two models make incremental adjustments to the historical-conventional system, which are mainly technological. The depth of these modifications depends on the technology used 
(optimizing synthetic inputs or using biological inputs) and on the scale of production. The legitimate worlds observed (market/ industrial compromise in the technology-intensive model $2 \mathrm{a}$ and domestic/industrial compromise in the biotech model $2 \mathrm{~b}$ ) result from these changes in practices and technologies, which are not morally neutral.

\section{The circular model based on industrial ecology efficiency compromise}

The third sustainable agriculture model (2c in Fig. 2) refers to a biological-input farming system embedded in both globalized food systems and a local circular economy. A circular economy aims at protecting and limiting the use of finite natural resources by the improved closure of material and energy cycles. This is achieved through recycling loops between economic agents (e.g., biogas production, recycling). Circular economies developed in opposition to linear and open management of material and energy flows in industrial supply chains, in which downstream pollution and waste emissions are spatially separated from upstream production systems. We termed this model the circular model.

Developing circular economies may require redesigning production systems, infrastructure, cultural frameworks, or social systems (Ghisellini et al. 2016). Drawing on industrial ecology, the circular model is based mainly on new ways of organizing farmers and other stakeholders into productive clusters. Geographical proximity is important in developing exchanges of materials, even energy. These organizations may also help redefine urban/rural relations. Developing local or regional circular economies enables farming systems to increase their territorial embeddedness by short-circuiting globalized supply chains for certain locally managed inputs and products. For example, this model can enable farming systems to substitute biological inputs (e.g., organic matter) for synthetic ones.

This new form of organization is recognized as valid by its proponents based on an industrial ethic of nature; i.e., on the shared idea that the natural organization of ecosystems is inherently efficient in allocating throughput of material and energy to the most useful activities at the ecosystem scale. Yet these organizational forms are only possible if the agents involved in these models conceive of productive efficiency at the local level. In this sense, in the circular model, the relationship with nature is part of the industrial world: waste and scrap are seen as resources to be exploited.

Contrary to the two previous models (technology-intensive and biotech), the adjustments to the historical-conventional system in the circular model are mainly organizational. However, the use of technology in the technological-intensive model and the circular economy in the circular model both seek to address the same criticisms about the conventional model's inefficiency (environmental and economic) and productivism. In the biotech and circular models, however, using technology responds to a deeper criticism of the harmful effects of the conventional model on nature and humans. Yet with all these type- 2 models, the criticisms of the conventional model do not question the value system (productivist principle) on which its legitimacy is based or its relationship to nature (technological mastery of productive capacity and the uncertainties of nature). In other words, they do not question the goal to be reached but rather the means of achieving it by questioning the ability of material and technical equipment and organizational forms to ensure productivity by controlling uncertainty. Implementing new practices thus only marginally disrupts the tests through which individual practices and organizations gain legitimacy.

\section{The diversified-globalized model based on opinion/industrial elements}

The fourth model (3a in Fig. 2) corresponds to biodiversity-based farming systems developed in socio-technical niches, such as those related to conservation agriculture, agroforestry, integrated croplivestock systems, and self-sufficient, grassland-based livestock systems. When no other solution exists or prices are attractive, farmers sell agricultural products in globalized commodity-based food supply chains, like the two first sustainable agriculture models (technology-intensive and biotech). We termed this model the diversified-globalized model. Yet diversified crops may be difficult to sell in this type of supply chain. They are then fed to animals (on the same farm or by trading between crop and animal farms), or farmers sell them directly to consumers, which is a form of alternative food system directly managed by the farmer.

This diversified-globalized model adopts production principles based on the work of nature, such as ecosystem services, without, however, prohibiting the use of synthetic or biological inputs. As with every biodiversity-based farming system (3a, $3 b$, and $3 c$ in Fig. 2), farmers in the diversified-globalized model have to integrate adaptive management of uncertainties about nature's functioning and the effects of practices. New upstream organizational forms of local and generic knowledge exchange are developed by farmers to deal with these uncertainties; e.g., peer groups for sharing experience on nature and farming practices. Such groups reshape the agronomic "rules of the game;" that is, they redefine what constitutes good farming practices, a "good" state of the field/farm, or the acceptable level of production. This way of organizing knowledge circulation takes advantage of concern about what others think, while at the same time it enables more firm judgments to be made about the common good. These peer groups thus establish a test based on opinions, which makes the set of production practices stable and coherent. These practices are supported by the effects of reputation, with a principle of legitimacy resulting from a compromise between the industrial world and the opinion world.

Two key features differentiate this model from the previous three: (i) nature is viewed as the main factor of production and as a place for humans to live, and (ii) new social forms of organization and of validating practices are introduced, not to increase productive efficiency but to reshape modes of production. Due to profound value differences, practices in the diversified-globalized model may be incompatible with the informational bases on which farmers justify their choices in type- 2 models; i.e. technologyintensive, biotech, and circular models (such as the technical references for agriculture associated with specialized farming systems and varieties/breeds).

\section{The relocalized model based on opinion/domestic/market elements}

The fifth model ( $3 \mathrm{~b}$ in Fig. 2) is a biodiversity-based farming system integrated into alternative food systems that seeks to meet local consumer and lifestyle demands for food quality, addedvalue distribution, localization, and environmental and human health issues. We termed this model the relocalized model, where 
local refers to both farming practices (possibly reinforced by circular economy) and the scale of product distribution.

This model may serve local or regional integrated food-energy systems. The objective is then to create synergies between food and energy production with potential positive influence on climate change. Developing integrated food-energy systems requires extending analysis, design, and assessment of agroindustrial ecology approaches. Organizing exchanges between economic agents and local populations raises important governance and social organization issues.

The upstream features of this model are the same as those in model $3 \mathrm{a}$, but while production in the latter is targeted to mass distribution markets, which requires a certain product standardization, in model $3 \mathrm{~b}$, products are distributed through local food systems. For farmers, this is justified by the desire to sell products of diversified crops that are difficult to sell in globalized food systems (as prices are too low for the farmer) and the desire to participate in the development of local food systems and the local economy. Two organizational forms that reveal two different types of common goods thus coexist: within peer communities, agronomic practices are submitted to the test of what constitutes good practices; and selling products within local food systems confronts farmers with consumers' judgments as a test of the environmental, organoleptic, and environmental and health quality of the products. This production world thus involves elements from the worlds of opinion, industry, and market in a compromise that is continually being recreated and may lead to conflict, even though the general values are shared (Coq-Huelva et al. 2017). Moreover, this compromise extends the social relationship to nature to a market test that puts producers and consumers face-to-face. This test fosters informal discussions with farmers and provides consumers who are qualified in this model (who want to reconnect with nature via their diet) with the more ecological and local interactions they seek.

However, even in this sustainable agriculture model, some raw products from biodiversity-based farming systems may still be sold through globalized food systems. Local and global markets are then considered to coexist and be complementary. As a result, this model is based on a shaky compromise.

\section{The integrated-landscape model based on green/domestic/civic elements}

An integrated landscape approach (3c in Fig. 2), which combines collective multiservice landscape management and the development of alternative food systems and circular economies, is the sixth sustainable agriculture model, termed the integratedlandscape model. As with the two previous models (diversifiedglobalized and relocalized), this one involves biodiversity-based farming systems. Strongly diversified organic farming systems based on ecosystem service enhancement and management are characteristic of these three models (contrary to the organic systems in biotech model $2 \mathrm{~b}$ ).

To develop this model, local populations seek to address the nexus of food/nonfood/natural resources, which determines the local to global sustainability of agriculture. Integrating the three drivers of diversification (collective, multiservice landscape management and the development of alternative food systems and circular economies) is a major concern for management at both individual (farm) and collective levels. On the one hand, supporting integrated landscape approaches requires that people be able to assess and analyze the trade-offs between objectives (including ecosystem services) and to define the associated compromises (Therond et al. 2017). On the other hand, managing multiservice landscapes requires clarifying the relative effects of landscape configuration and composition and those of cropping systems (field level) for different ecosystem services (e.g., Duru et al. 2015a, Tamburini et al. 2016).

The main concerns are natural resource management, ecological integrity, landscape multifunctionality, human welfare, and local social dynamics. This requires acknowledging the environment and humanity as common goods. The integrated landscape model is then characterized by systemic thinking at the local level, with landscape considered as a social-ecological system in which land use allocation, resource management (including ecosystem services), and well-being are key issues. Adopting systemic thought justifies not only choosing production modes based on the work of nature (such as ecosystem services and biodiversity) but also including agriculture in a circular economy and in local food systems.

The privileged form of organization for landscape-scale integrated management is the social network. Public projects are often decisive in structuring these sorts of collective initiatives. This form of organization establishes the fair treatment of all members as in the civic world. In this model, socially legitimate agricultural practices are those that contribute to local development. This system borrows elements of legitimacy from the domestic world (reconsidering the local area as a space in which proximity of socioeconomic interactions and the environment are particularly important) and the civic world (fair treatment of the stakeholders in the local network, possibly extended to equity between localized societies and ecosystems). It also opens the way for forms of justification from the ecological world (green polity). In this model, nature is understood as an organized ensemble of living beings whose actors recognize its intrinsic value as well as its productive value.

The relocalized (3b) and integrated-landscape (3c) models fundamentally break with the conventional and type- 2 models in which principles from the industrial world predominate. These two models ( $3 \mathrm{~b}$ and $3 \mathrm{c}$ ), and to a lesser extent the diversifiedglobalized model (3a), are based on very different relationships to nature, which can be seen in agricultural products with ambitious Designation of Origin Labels, for example. While in type- 2 models nature is viewed as an uncertain production vector (which therefore must be controlled), in biodiversity-based farming systems (type-3 models), agricultural ecosystems are seen as living entities, and putting them to work requires diagnostics, listening, and possibly "dialogue." While in type- 2 models most practices are standardized and removed from the local context, in type-3 models practices are situated locally and based on applying agronomic knowledge and even vernacular or traditional knowledge (such as suitable cover crops, crop rotations). The (re)construction and testing of the effectiveness of this knowledge are done in a pragmatic (in the sense of thinking in action) and experiential way. 


\section{DISCUSSION}

There are many values used to justify how practices, technologies, and rules, and the ways of organizing and institutionally regulating agriculture come together in a stable and coherent model. By taking this into account, we created a new characterization of the multiple models of agriculture that currently coexist in Western economies. While this characterization is static, it enables us to discuss the various agricultural challenges of agroecological transitions. The literature in sustainable transition studies (Geels and Schot 2007, Smith and Stirling 2010, van den Bergh et al. 2011), in fact, emphasizes "a set of connected changes, which reinforce each other but take place in several different areas, such as technology, the economy, institutions, behavior, culture, ecology and belief systems" (Rotmans et al. 2001:16). Certain authors underline the uniqueness of approaches that "focus on the socio-cultural context of socio-technical and innovation systems, in contrast to the more economic and market focus of [evolutionaryinstitutional economists]" (Borrás and Edler 2014:7). These sociocultural aspects have been considered important but have not yet been described in any detail. Thus, studying the value systems that characterize the different registers of action (see Table 1) helps us better understand the drivers of change in socio-technical systems. It also enables us to analyze the coexistence and coevolution of multiple agriculture models. We now turn to examine these issues through two fundamental aspects involved in the dynamics of change: lock-in, which we analyze as a process of legitimacy/disqualification, and the nature of transitions.

\section{Legitimation and disqualification as processes for change and lock-in}

The institutional analysis of sustainable agriculture models by Therond et al. (2017) revealed the diversity of ways in which the values mobilized in those worlds order social relationships. Classifying and characterizing farming practices in their socioeconomic contexts objectifies the role of social values as principles of justice that organize collective action. This leads to (i) identifying the elements in each model (using convention theory) that legitimize the orders of worth prevailing in that model, and (ii) disqualifying the elements that are incompatible with the principles underlying the practices. The processes of disqualification can then apply to certain kinds of knowledge, involving a certain way of organizing ignorance (Frickel and Vincent 2007). The conventional agriculture model became dominant precisely because its practices and organizational modes were legitimized by referring to principles of justice (the idea that progress benefits the farmer through higher income, the consumer through reduced purchase price, and rural areas by redistributing value) and by referring to certain values (principles of streamlining and production efficiency). Today, it is precisely by calling on these principles that the historical-conventional model disqualifies criticisms from an ecological perspective, namely that the idea of progress embodied in equipment for modernizing agriculture has betrayed a different idea, that of human development (Norgaard 1994). These disqualified criticisms may then become the basis for another agricultural model (for example, the integrated-landscape model 3c).

These two symmetrical mechanisms of legitimation and disqualification explain the degree of stability and coherence of various agricultural worlds. Indeed, some models are more stable, while others are more vulnerable to internal or external shocks or criticisms. More importantly, we have identified the element(s) of social systems that are constitutive of a given model's evolution. For example, models deeply connected to global food systems are qualified by the conventional norms of the historical model (e.g., product standards or commodity markets), which makes them more stable than other models but also more exposed to external market risks (mostly price and cost variability). Models based on chemicals and technology (2a, 2b, 3a, and, to a lesser extent, 2c) are more vulnerable to hazards coming from natural external environments because they do not require extensive knowledge about the functioning of agroecosystems. The relocalized (3b) and integrated-landscape (3c) models are vulnerable because of their internal weakness. In fact, collective actions in these models are downscaled because there is no widely accepted practical test (here, in the sense of the economies of worth; i.e., a setup enabling a social ranking of people and practices from the most to the least valuable regarding a common good) that objectifies the merits of various practices in regard to common goods.

Legitimation and disqualification also enable us to see how lockin works. For example, intellectual property rights play a fundamental role in the historical-conventional model, since they encourage private research and development (e.g., bringing to market new seed varieties). Yet regulating farming practices through intellectual property rights (and through the markets that result) may discourage certain initiatives that want to implement practices from the diversified-globalized (3a) and/or relocalized models (3b). For instance, initiatives for exchanging seeds are viewed as social and organizational innovations in diversifiedglobalized (3a) and relocalized models (3b), in that they address numerous criticisms of the historical-conventional model (Pautasso et al. 2013). Yet in models with technological innovation protected by intellectual property rights, such as the technology-intensive model based on efficiency (2a) and the biotech model based on biocontrol (2b), exchanging seeds is illegitimate.

These mechanisms of legitimization and disqualification serve to make agricultural models a logical whole. While legitimizing and disqualifying establish the coherence specific to a given world and ensure efficient forms of coordination, making a set of arrangements coherent also "naturalizes" conventional practices, in that the actors consider those practices natural or self-evident. Moreover, this reproduces the modes of collective regulation that occur within that given model. In this sense, our characterization provides a richer framework for grasping the resistance to change. First, it avoids reducing resistance to change to mere lock-in that is exclusively technological and disconnected from the social context in which that resistance occurs. Second, it does not assume that resistance to change is caused merely by human nature or social structures that dictate the behaviors of actors from the outside.

\section{The plurality of transition pathways: coevolution and complementarity}

Our analysis of sustainable agriculture models also shows how these models can coevolve in transitioning to a new model such as agroecology. Each model identified is made up of compromises among values, referring to social orders that vary in stability or fragility depending on their institutional, cognitive, and material 
sets of arrangements. The historical-conventional model (1) is "conventional" in that it results from a historical process of institutions and organizations aligning with the values that underlie the main mode of organization in Western economies: industrial and market capitalism. The ways in which the conventional model responds to criticism from the ecological world may lead to two types of sustainable transition depending on whether the criticisms are addressed to the set of arrangements flowing from the principles of the conventional model (that is, the principle of justice that underpins it), or, more radically, to the principles themselves. Two types of transition pathways can, therefore, be distinguished according to the kind of criticism made of the conventional model. Transition is therefore understood as a matter of intensity of change from incremental to radical. For example, in the diversified-globalized (3a) and relocalized (3b) models, it is the principle of opinion in peer groups that ensures the circulation of experiential knowledge. Yet this type of knowledge circulation fundamentally challenges the principle that it should be industry that organizes knowledge production, diffusion, and even protection through intellectual property rights, as in the technology-intensive model $2 \mathrm{a}$.

In the first type of transition (incremental change), the conventional model requalifies the environmental criticisms directed at it by shifting focus to the means (technologies, practices) used to attain the common good, thereby avoiding any discussion of the very foundation or definition of the common good. The idea is thus to implement the appropriate means to ensure that productivist objectives continue to be met while responding to ecological criticisms. This type of transition for the conventional model is proposed by the technology-intensive model based on efficiency ( $2 a)$, the biotech model ( $2 b)$, and to a lesser extent, by the circular model (2c). The technological and practical adjustments made to the conventional model thus do not fundamentally call into question the modes of organization on which this model is based (Marsden 2012). The circular model (2c) constitutes a "new" form of productive organization that is collectively accepted because it is compatible with the underlying values of the conventional model (i.e., the search for productive efficiency). As a result, the ethical difference in the biotech model (2b) or in the circular model (2c) is unlikely to jeopardize the overall organization of the conventional model; at most, it helps create an additional market for biological inputs or upscale the way agricultural production is organized.

The second type of possible transition (more radical change) involves a profound challenge to the values underlying the conventional model (as well as type- 2 models). While here, producing value remains an important goal for economic actors in agriculture, integrating the ways ecosystems work into production process implies a different relationship with nature and more profound changes in the social values involved. The material, technological, and institutional set of arrangements used in conventional and type- 2 models are thus challenged, not because they are not productive or cannot improve profitability, but because they do not support the value system that makes the diversified-globalized (3a), relocalized (3b), and integrated landscape models (3c) coherent. The nature of this second transition is different from the more incremental or reformist one, since it involves a break with the values, the modes of production and organization, and the narrow relationship to nature in the conventional model. Assuming that the drivers of change are coherent with the models they seek to change, which is necessary for them to be effective, this second transition path has the potential to be revolutionary (Holt-Giménez and Altieri 2012).

Finally, our characterization also reveals a third way for change (hybridization between models) that questions and complements the "socio-technical transition" identified by Geels and Schot (2007), which they conceive of as "pathways." These authors argue that the distribution of niches - i.e., networks of actors that develop outside the dominant regime - is supposed to help that dominant regime evolve (Geels 2011), yet the conditions for wide diffusion remain unexplained. Geels and Schot (2007:402) state that "both niche and regime communities share certain rules that coordinate action," but they do not explain how those rules can be made compatible, nor do they expand on the importance of moral foundations in rules for collective action. Although the hypothesis of their multilevel model is that niches are separate spaces where radical innovation occurs, it cannot occur in the dominant regime because it is too locked-in to routines. On the contrary, our analysis offers new avenues for understanding how a new sustainable agriculture model, based on a principle of legitimacy that differs from the dominant regime, can spread within that dominant regime. For example, growing species that improve diversification (such as grain legumes) and enable rotations to be lengthened are agricultural practices of the diversified-globalized model (3a). Yet this practice finds a certain legitimacy from the principles of the conventional model since it gives rise to new product outlets that may provide better pay for farmers (Magrini et al. 2016). The dominant regime can thus rely on, and even hybridize, niches that are organized around practices and forms that are, in theory, incompatible. This is because niches enable the dominant regime to better meet society's demands and to maintain its existence (developing a market for biological inputs and the biotech model [2b] are such adjustments to the conventional model).

This hybridization between agricultural models based on various registers of action ultimately suggests that the agroecological transition of farming systems can be based on a combination of elements from different models. This complementarity paves the way for a new conceptualization of change in which models coevolve by relying on arrangements of varying stability and duration. This mode of transition does not relate to intensity, as in the distinction between incremental and radical change, but rather to a change in the nature of transition. Thus, we would assert that there is a near infinite complexity of the ways in which these models can be combined.

\section{CONCLUSION}

We offer a first attempt at identifying and finely characterizing multiple agriculture models that address sustainability, and do so in both agronomical and institutional terms. We have identified the institutional characteristics of seven agriculture models initially defined in an agroecological perspective. In particular, we have focused on the opposition between the historicalconventional model, based on industrial organization and market principles, and six alternative sustainable agriculture models that seek to address the challenges of environmental sustainability. Moreover, the ways in which these agricultural models use different practices and technologies to organize and regulate 
agricultural production has been examined, in addition to how each model qualifies ways of doing and acting depending on the value system that justifies how they implement sustainability in the eyes of society. We have also drawn attention to the complexity of the agricultural panorama in which these models coexist and coevolve to varying degrees, and to the fact that multiple transition pathways toward more agroecological agriculture may emerge.

Ultimately, this study has implications for effective public policymaking. First, the ways in which policies are implemented must be coherent with the agriculture models that they seek to modify or sustain: they must take into account the reasons why actors in those models act and how they act. Moreover, to be effective, policies need to address the characteristics of models they seek to change and the multiple ways in which these models may coexist, intertwine, and coevolve over time. For now, we advocate a precautionary principle so that more marginal models are not prevented from emerging or developing. This would have two advantages. First, as we have suggested, there is some porosity between these models. The practical and organizational innovations in the models that differ most radically from the conventional model can contribute to the more established sustainable agriculture models and improve their sustainability. Second, the systemic nature of the agroecological transition requires profound moral and philosophical changes in how we conceive of our relationship to nature. This is a unique characteristic of the more marginal models.

More research is needed to understand in greater detail this characterization of agriculture models and their transitioning processes. In future studies, we intend to pursue the theoretical reflections advanced here by (i) determining the proportion of farmers who have adopted each of these models; (ii) identifying the configurations of coexistence or combinations of these models in developed countries by analyzing numerical data (agricultural surface area, nature of rotations, added-value, product nature and volume, type of market(s); and (iii) assessing the sustainability of these configurations using multicriteria evaluations.

Responses to this article can be read online at: http://www.ecologyandsociety.org/issues/responses. $\mathrm{php} / 9881$

\section{Acknowledgments:}

This research was conducted as part of the TATABOX project, funded by the French Research Agency ( ANR 13 - AGRO - 0006). We would like to thank the referees for their insightful comments that helped improve the paper. We also are grateful to Cynthia J. Johnson who translated this text into English.

\section{LITERATURE CITED}

Allaire, G., and S. Bellon. 2014. L'AB en 3D: Diversité, dynamiques et design de l'agriculture biologique. Agronomie, Environnement and Sociétés 4:79-90.
Argyris, C., and D. A. Schön. 1996. Organizational learning II: theory, method and practice. Addison-Wesley, Reading, Massachusetts.

Boltanski, L., and L. Thévenot. 2006. On justifications: the economies of worth. (French Edition, 1991). Princeton University Press.

Borrás, S., and J. Edler. 2014. Introduction: on governance, systems and change. Pages 1-22 in S. Borrás and J. Edler, editors. The governance of socio-technical systems: explaining change. Edward Elgar Publishing, Cheltenham, UK. http://dx.doi. org/10.4337/9781784710194.00010

Coq-Huelva, D., J. Sanz-Cañada, and F. Sánchez-Escobar. 2017. Values, conventions, innovation and sociopolitical struggles in a local food system: conflict between organic and conventional farmers in Sierra de Segura. Journal of Rural Studies 55:112-121. http://dx.doi.org/10.1016/j.jrurstud.2017.08.002

Duru, M., O. Therond, and M. Fares. 2015a. Designing agroecological transitions: a review. Agronomy for Sustainable Development 35:1237-1257. http://dx.doi.org/10.1007/s13593-015-0318$\mathrm{x}$

Duru, M., O. Therond, G. Martin, R. Martin-Clouaire, M.-A. Magne, E. Justes, E.-P. Journet, J.-N. Aubertot, S. Savary, J.-E. Bergez, and J. P. Sarthou. 2015b. How to implement biodiversitybased agriculture to enhance ecosystem services: a review. Agronomy for Sustainable Development 35:1259-1281. http://dx. doi.org/10.1007/s13593-015-0306-1

Duru, M., O. Therond, J. Roger-Estrade, and G. Richard. 2016. Agriculture models at the crossroads of farming systems, food systems and territorial dynamics. Pages 12-15 in 12th European IFS A Symposium. Edgmond, UK.

Frickel, S., and M. B. Vincent. 2007. Hurricane Katrina, contamination, and the unintended organization of ignorance. Technology in Society 29:181-188. http://dx.doi.org/10.1016/j. techsoc.2007.01.007

Geels, F. W. 2011. The multi-level perspective on sustainability transitions: responses to seven criticisms. Environmental Innovation and Societal Transitions 1:24-40. http://dx.doi. org/10.1016/j.eist.2011.02.002

Geels, F. W., and J. Schot. 2007. Typology of sociotechnical transition pathways. Research Policy 36:399-417. http://dx.doi. org/10.1016/j.respol.2007.01.003

German, R. N., C. E. Thompson, and T. G. Benton. 2016. Relationships among multiple aspects of agriculture's environmental impact and productivity: a meta-analysis to guide sustainable agriculture. Biological Reviews 92:716-738. http://dx. doi.org/10.1111/brv.12251

Ghisellini, P., C. Cialani, and S. Ulgiati. 2016. A review on circular economy: the expected transition to a balanced interplay of environmental and economic systems. Journal of Cleaner Production 114:11-32.

Gliessman, S. R. 2007. Agroecology: the ecology of sustainable food systems. Lewis Publishers, Boca Raton, Florida, USA. 
Hill, S. B. 1998. Redesigning agroecosystems for environmental sustainability: a deep systems approach. Systems Research and Behavioral Science 15:391-402. http://dx.doi.org/10.1002/(SICI) 1099-1743(1998090)15:5<391::AID-SRES266>3.0.CO;2-0

Holt-Giménez, E., and M. A. Altieri. 2012. Agroecology, food sovereignty, and the new green revolution. Journal of Sustainable Agriculture 37:90-102. http://dx.doi.org/10.1080/10440046.2012.716388

Horlings, L. G., and T. K. Marsden. 2011. Towards the real green revolution? Exploring the conceptual dimensions of a new ecological modernisation of agriculture that could 'feed the world'. Global Environmental Change 21:441-452. http://dx.doi. org/10.1016/j.gloenvcha.2011.01.004

Khoury, C. K., A. D. Bjorkman, H. Dempewolf, J. RamirezVillegas, L. Guarino, A. Jarvis, L. H. Rieseberg, and P. C. Struik. 2014. Increasing homogeneity in global food supplies and the implications for food security. Proceedings of the National Academy of Sciences of the United States of America 111:40014006. http://dx.doi.org/10.1073/pnas. 1313490111

Lemanceau, P., P.-A. Maron, S. Mazurier, C. Mougel, B. Pivato, P. Plassart, L. Ranjard, C. Revellin, V. Tardy, and D. Wipf. 2015. Understanding and managing soil biodiversity: a major challenge in agroecology. Agronomy for Sustainable Development 35:67-81. http://dx.doi.org/10.1007/s13593-014-0247-0

Levidow, L., K. Birch, and T. Papaioannou. 2013. Divergent paradigms of European agro-food innovation: the knowledgebased bio-economy (KBBE) as an R\&D agenda. Science, Technology, \& Human Values 38(1):94-125. http://dx.doi. org/10.1177/0162243912438143

Magrini, M.-B., M. Anton, C. Cholez, G. Corre-Hellou, G. Duc, M.-H. Jeuffroy, J.-M., Meynard, E. Pelzer, A.-S. Voisin, and S. Walrand. 2016. Why are grain-legumes rarely present in cropping systems despite their environmental and nutritional benefits? Analyzing lock-in in the French agrifood system. Ecological Economics 126:152-162. http://dx.doi.org/10.1016/j.ecolecon.2016.03.024

Marsden, T. K. 2011. From post-productionism to reflexive governance: contested transitions in securing more sustainable food futures. Journal of Rural Studies 29:123-134. http://dx.doi. org/10.1016/j.jrurstud.2011.10.001

Marsden, T. K. 2012. Towards a real sustainable agri-food security and food policy: beyond the ecological fallacies? Political Quarterly 83:139-145. http://dx.doi.org/10.1111/j.1467-923X.2012.02242. $\underline{x}$

Monteiro, C. A., J.-C. Moubarac, G. Cannon, S. W. Ng, and B. Popkin. 2013. Ultra-processed products are becoming dominant in the global food system. Obesity Reviews 14:21-28. http://dx. doi.org/10.1111/obr.12107

Müller, B., and D. Kreuer. 2016. Ecologists should care about insurance, too. Trends in Ecology \& Evolution 31:1-2. http://dx. doi.org/10.1016/j.tree.2015.10.006

Norgaard, R. B. 1994. Development betrayed: the end of progress and a co-evolutionary revisioning of the future. Routledge, London, UK.

O'Kane, G. 2012. What is the real cost of our food? Implications for the environment, society and public health nutrition. Public
Health Nutrition 15:268-276. http://dx.doi.org/10.1017/ $\underline{\text { S136898001100142X }}$

Park, S. E., N. A. Marshall, E. Jakku, A. M. Dowd, S. M. Howden, E. Mendham, and A. Fleming. 2012. Informing adaptation responses to climate change through theories of transformation. Global Environmental Change 22:115-126. http://dx.doi. org/10.1016/j.gloenvcha.2011.10.003

Pautasso, M., G. Aistara, A. Barnaud, S. Caillon, P. Clouvel, O. T. Coomes, M. Delêtre, E. Demeulenaere, P. De Santis, T. Döring, L. Eloy, L. Emperaire, E. Garine, I. Goldringer, D. Jarvis, H. Joly, C. Leclerc, S. Louafi, P. Martin, F. Massol, S. Mcguire, D. B. Mckey, C. Padoch, C. Soler, M. Thomas, and S. Tramontini. 2013. Seed exchange networks for agrobiodiversity conservation. A review. Agronomy for Sustainable Development 33:151-175. http:// dx.doi.org/10.1007/s13593-012-0089-6

Ponte, S. 2016. Convention theory in the Anglophone agro-food literature: past, present and future. Journal of Rural Studies 44:1223. http://dx.doi.org/10.1016/j.jrurstud.2015.12.019

Rockström, J., W. Steffen, K. Noone, A. Persson, F. S. Chapin, E. F. Lambin, T. M. Lenton, M. Scheffer, C. Folke, H. J. Schellnhuber, B. Kykvist, C. A. de Wit, T. Hughes, S. van der Leeuw, H. Rodhe, S. Sörlin, P. K. Snyder, R. Costanza, U. Svedin, M. Falkenmark, L. Karlberg, R. C. Corell, V. J. Fabry, J. Hansen, B. Walker, D. Liverman, K. Richardson, P. Crutzen, and J. A. Foley. 2009. A safe operating space for humanity. Nature 461:472475. http://dx.doi.org/10.1038/461472a

Rotmans, J., R. Kemp, and M. van Asselt. 2001. More evolution than revolution: transition management in public policy. Foresight 3:15-31. http://dx.doi.org/10.1108/14636680110803003

Smith, A., and A. Stirling. 2010. The politics of social-ecological resilience and sustainable socio-technical transitions. Ecology and Society 15(1):11. http://dx.doi.org/10.5751/ES-03218-150111

Sonnino, R., and T. Marsden. 2006. Beyond the divide: rethinking relationships between alternative and conventional food networks in Europe. Journal of Economic Geography 6:181-199. http://dx. doi.org/10.1093/jeg/lbi006

Spiertz, H. 2012. Avenues to meet food security. The role of agronomy on solving complexity in food production and resource use. European Journal of Agronomy 43:1-8.

Tamburini, G., S. De Simone, M. Sigura, F. Boscutti, and L. Marini. 2016. Conservation tillage mitigates the negative effect of landscape simplification on biological control. Journal of Applied Ecology 53:233-241. http://dx.doi.org/10.1111/1365-2664.12544

Therond, O., M. Duru, J. Roger-Estrade, and G. Richard. 2017. A new analytical framework of agriculture model and farming system diversities to identify knowledge gaps in agronomy research: a review. Agronomy for Susainable Development 37:21.

Thévenot, L. 1984. Rules and implements: investment in forms. Social Science Information 23:1-45. http://dx.doi. org/10.1177/053901884023001001

van den Bergh, J. C. J. M., B. Truffer, and G. Kallis. 2011. Environmental innovation and societal transitions: introduction and overview. Environmental Innovation and Societal Transitions 1:1-23. http://dx.doi.org/10.1016/j.eist.2011.04.010 
Wilson, G. A. 2008. From 'weak' to 'strong' multifunctionality: conceptualising farm-level multifunctional transitional pathways. Journal of Rural Studies 24:367-383. http://dx.doi.org/10.1016/j. jrurstud.2007.12.010

Zhang, W., T. H. Ricketts, C. Kremen, K. Carney, and S. M. Swinton. 2007. Ecosystem services and dis-services to agriculture. Ecological Economics 64:253-260. http://dx.doi.org/10.1016/j. ecolecon.2007.02.024 